\title{
Clinical course, late results, and pathological nature of inflammatory disease of the colon initially sparing the rectum
}

\author{
BURTON I. KORELITZ
}

\begin{abstract}
From the Division of Gastroenterology, Department of Medicine, the Mt. Sinai Hospital, New York, U.S.A.
\end{abstract}

EDITORIAL COMMENT This study brings out the high proportion of patients with inflammatory disease of the colon initially sparing the rectum who have granulomatous disease and not idiopathic proctocolitis.

In the large clinical studies of ulcerative colitis from many institutions over the past three decades, approximately $8 \%$ of the cases have been described as 'right-sided', 'segmental', or 'regional'. While the clinical features in most were more consistent with regional ileitis than ulcerative colitis, the distribution of the disease process was primarily or totally colonic. The one common denominator was the lack of involvement of the rectal mucosa.

The natural history of patients with inflammatory colonic disease sparing the rectum has not been determined. The probability of extension of disease to the rectal segment or terminal ileum either spontaneously or following definitive surgery has not been clarified. The nature of the colonic pathology has not been correlated with the initial sparing of the rectal segment, despite the fact that clinical similarity to regional ileitis suggests granulomatous disease. Nor has it been determined whether radiological features characteristic of granulomatous disease should be expected nor whether and how often the $x$-ray picture of the colon is more consistent with ulcerative colitis.

The objectives of the present study are to clarify these issues upon which proper management depends, by correlating the clinical course, the results of surgical procedures, the findings at followup, and the radiological and pathological reports.

\section{MATERIALS AND METHODS}

The records of patients with ulcerative colitis or ileocolitis who were admitted to the Mt. Sinai Hospital between 1952 and 1961 were reviewed. Those cases in which an adequate sigmoidoscopy for a minimum distance of $14 \mathrm{~cm}$., performed by the attending gastroenterologist or surgeon early in the course of the illness, revealed the rectal mucosa to be free of disease, provided the material for this study. Though rectal biopsy in two instances showed evidence of chronic inflammation when the gross appearance was normal, this did not serve to exclude those cases, in that so few biopsies of normalappearing tissue were done at all. Neither were a few cases eliminated when there was some evidence of recto-sigmoidal involvement while the rectum appeared completely normal. A case was not excluded in the presence of a recto-vaginal fistula or perianal ulceration or suppuration when the rectal mucosa was otherwise without friability or other indication of active disease. On the other hand, if the first sigmoidoscopy proved to be normal while the patient was in the course of steroid therapy or soon after completion of a period of treatment with steroid medication, the case was eliminated since the rectum might have been involved earlier and already have markedly improved with such therapy. Patients who had had extension of inflammatory disease to the colon following internal anastomoses (with or without ileocolectomy for regional ileitis) were also excluded from this study.

There were 94 patients in the total group in whom inflammatory disease of the colon initially spared the rectum. This represented approximately $12 \%$ of all 
cases of ulcerative colitis admitted to the hospital during that period. There were 40 men and 54 women. The mean age at onset of disease was 21 years with a range of 8 to 60 years.

After the early results were evaluated, these patients were followed or traced until 1965 to ascertain late results. The mean length of follow-up was 14 years with a range of four to 36 years in living patients.

\section{RESULTS}

CLINICAL FEATURES The most common primary symptoms and physical findings before any surgical intervention and their frequency are recorded in Table I. Abdominal pain was localized to the right lower quadrant in 17 cases and to other quadrants in 10. Though blood per rectum was recorded in 42 cases, this was not representative of the clinical picture in 28. In 12 of these, bleeding was always a minor symptom and in a few it was associated with haemorrhoids or rectal suppuration. In three there was bleeding on one occasion only, in one on two occasions, and in two on three occasions. In one there was bleeding at the onset only and in five only late in the course of the disease. In four when rectal bleeding occurred at all it was massive.

\section{TABLE I}

CLINICAL FEATURES IN 94 CASES OF INFLAMMATORY DISEASE OF THE COLON INITIALLY SPARING THE RECTUM

\begin{tabular}{lccc}
$\begin{array}{l}\text { Symptom or Physical } \\
\text { Finding }\end{array}$ & \multicolumn{2}{c}{ No. of Cases } & $\begin{array}{c}\text { Insufficient } \\
\text { Information }\end{array}$ \\
\cline { 2 - 3 } & Present & Absent & \\
\hline Diarrhoea & 79 & 4 & 11 \\
Fever & 54 & & 40 \\
Abdominal pain & 73 & & 21 \\
Localization of pain & 27 & & \\
Abdominal mass & 10 & & 51 \\
Weight loss & 43 & 22 & 30 \\
Blood per rectum & $42^{1}$ & 22 & \\
1Inconsistent symptom in 28. & & &
\end{tabular}

In at least seven cases in which early in the course the primary bowel symptoms were absent, fever in association with joint pains or a heart murmer merited consideration of the diagnosis of rheumatic fever.

In four cases there was a history of 'ulcerative colitis' in close relatives (daughter, mother, brother, father), three of whom died of their disease.

COMPLICATIONS The local or primary complications are recorded in Table II, and the systemic complications in Table III. Fistulae often occurred at more than one site in the same patient and many patients had more than one type of complication.
TABLE II

LOCAL COMPLICATION IN 94 CASES OF INFLAMMATORY DISEASE OF THE COLON INITIALLY SPARING THE RECTUM No. of Cases

\begin{tabular}{lrr}
\hline Fistulae & 50 & 30 \\
$\quad$ Anal or perirectal & & 13 \\
$\quad$ Recto-vaginal & & 5 \\
$\quad$ Perineal & & 11 \\
$\quad$ Vulval & & 21 \\
$\quad$ Ileum to abdominal wall & & \\
$\quad$ Internal, from ileum or colon & 18 & \\
External abscesses & 4 & \\
Ulceration of anus & 3 & \\
Toxic dilatation of colon & 7 & \\
Perforation of colon & 2 & \\
Perforation of ileum & 11 & \\
Haemorrhage from rectum & 16 & 4 \\
Stricture of rectum & \\
$\quad$ After colonic surgery & & \\
$\quad$ Without surgery & & \\
Stricture of colon & 13 & \\
$\quad$ After colonic surgery & & \\
$\quad$ Without surgery & &
\end{tabular}

TABLE III

SYSTEMIC COMPLICATIONS IN 94 CASES OF INFLAMMATORY DISEASE OF THE COLON INITIALLY SPARING THE RECTUM

\begin{tabular}{lc} 
& No. of Cases \\
\hline Arthralgias or arthritis & 33 \\
Erythema nodosum & 9 \\
Clubbing & 6 \\
Retarded growth & 6 \\
Stomatitis & 3 \\
Iritis & 3 \\
Thrombophlebitis & 2 \\
Pulmonary emboli & 3 \\
Leg ulcerations & 2 \\
Parotitis & 1 \\
Malabsorption & 3 \\
Electrolyte imbalance & 1 \\
Osteoporosis & 2 \\
Vertebral collapse & 1 \\
Nephrolithiasis & 8 \\
Amyloidosis & 1 \\
Retrobulbar neuritis & 1 \\
Phagedenic ulcer & 1 \\
Gram-negative septicaemia & 2
\end{tabular}

EXTENT OF INFLAMMATORY DISEASE The segments of involvement in the inflammatory disease process were determined in most cases by barium enema radiographs and small bowel $x$-ray examinations and further determined in 70 cases by the exploration or surgical specimen. In four the extent was determined by the surgical procedure only without satisfactory radiological information. The distribution of involvement in the colon and small bowel is noted in Table IV. In 11 cases more than one foot of small bowel was involved, including two with disease extending to the jejunum. In 12 cases the initial barium enema $x$-ray examination was considered normal and in five of these the patient was considered to have ileitis. In at least three both the barium enema and small bowel studies were originally normal and in two of these inflammatory disease remained unrecognized even at exploration. 
TABLE IV

EXTENT OF INFLAMMATORY DISEASE IN COLON AND ILEUM IN 94 CASES SPARING THE RECTUM

\begin{tabular}{lcc} 
Distribution in Colon & $\begin{array}{c}\text { No. of } \\
\text { Cases }\end{array}$ & $\begin{array}{l}\text { No. of Cases with } \\
\text { Terminal Ileum } \\
\text { Involved }\end{array}$ \\
\hline Caecum to sigmoid & 33 & $25^{2,1}$ \\
Caecum to descending & 10 & $\mathbf{8}^{\mathbf{2}}$ \\
Caecum to distal transverse & 5 & $4^{1}$ \\
Caecum to proximal transverse & 10 & $9^{1}$ \\
Caecum to ascending & 6 & $5^{2,1}$ \\
Caecum & 2 & \\
Ascending to sigmoid & 1 & $1^{2,1}$ \\
Ascending to descending & $4^{2}$ & 1 \\
Ascending to transverse & 2 & \\
Transverse to sigmoid & 2 & \\
Transverse to descending & 1 & 53 \\
Descending to sigmoid & 1 & \\
Insufficient information & $17^{2}$ & \\
Total & 94 &
\end{tabular}

'Eleven with more than one foot of small bowel disease.

${ }^{3}$ Nine with skip areas in colon.

RESULTS OF MEDICAL THERAPY The medical programme consisting of various combinations of bed rest, enforced nutrition, sedation, psychotherapy, infusions, transfusions, opiates, sulphonamide drugs, and antibiotics was supplemented with adrenocorticotrophic hormone or adrenal steroids or both in at least 51 cases. Of the 40 patients who came to surgery without previous hormonal therapy, 25 were operated on in the pre-steroid era. Of the other 28 surgical patients at least 26 had previously improved coincident with steroid therapy at some time.

Of the 26 patients who were managed without surgery until the time of follow-up, 23 received steroids at some time. These cases have been followed for from four to 25 years (mean 11 years). In only three cases were the steroids gradually reduced and stopped within months and not required again. In three cases therapy was continued for one to three years and then stopped. Ten patients received steroids intermittently for two to 15 years (mean 9 years) and six patients constantly for three to nine years (mean seven years). One other patient died after two years of disease due to complications probably contributed to by the steroid agents.

At the time of follow-up of the 22 living steroidtreated non-operated patients, 12 were well and 10 had recurrent symptoms. In two patients growth and development have been retarded though they are otherwise well. One patient had diffuse ileojejunitis with a malabsorption syndrome and strictures of the ileum. Two had had minor surgery performed for perirectal abscesses, one with resulting rectal incontinence. Two had had other severe diseases. There were three additional non-operative patients who never received steroids and had been well for four, 10, and 14 years.

INDICATIONS FOR OPERATIVE INTERVENTION In Table $\mathrm{V}$ are listed the surgical indications with emphasis on a single complication when it was the obvious deciding factor. In 25 of the 68 cases the first definitive surgery was performed before 1951 after a mean of two years of disease. In the other

\section{TABLE V}

INDICATIONS FOR DEFINITIVE SURGERY IN 68 CASES OF INFLAMMATORY DISEASE OF COLON INITIALLY SPARING THE RECTUM

\begin{tabular}{l} 
Indication \\
\hline Chronic disease \pm acute exacerbation \\
Abdominal mass or abscess \pm fistula \\
Perforation \\
Obstruction \\
Internal fistula \\
Haemorrhage \\
Perirectal complications \\
Possible carcinoma of colon \\
Uncertain \\
Total
\end{tabular}

No. of Cases

TABLE VI

INITIAL AND LATER DEFINITIVE OPERATIVE PROCEDURES IN 68 CASES OF INFLAMMATORY DISEASE OF THE COLON INITIALLY SPARING THE RECTUM

\begin{tabular}{|c|c|c|c|c|c|c|c|c|c|}
\hline Initial Definitive Operation & $\begin{array}{l}\text { No. of } \\
\text { Cases }\end{array}$ & $\begin{array}{l}\text { No. of Cases } \\
\text { of Later } \\
\text { Colonic } \\
\text { Resection }\end{array}$ & $\begin{array}{l}\text { No. of Cases } \\
\text { of New Ileo- } \\
\text { colostomy } \pm \\
\text { Resection }\end{array}$ & $\begin{array}{l}\text { No. of } \\
\text { Cases of } \\
\text { Ileostomy }\end{array}$ & $\begin{array}{l}\text { No. of } \\
\text { Cases of } \\
\text { Ileal } \\
\text { Resection }\end{array}$ & $\begin{array}{l}\text { No. of Cases } \\
\text { of New } \\
\text { Ileostomy } \pm \\
\text { Resection }\end{array}$ & $\begin{array}{l}\text { No. of Cases } \\
\text { of } \\
\text { Abdomino- } \\
\text { perineal } \\
\text { Resection }\end{array}$ & $\begin{array}{l}\text { No. of Cases } \\
\text { of Total } \\
\text { Procto- } \\
\text { colectomy }\end{array}$ & $\begin{array}{l}\text { No. of Cases } \\
\text { of Re- } \\
\text { anastomosis }\end{array}$ \\
\hline $\begin{array}{l}\text { Ileocolostomy } 1 \\
\text { Ileocolostomy, }{ }^{2} \text { subtotal }\end{array}$ & 18 & 12 & 5 & 11 & 2 & 2 & 6 & 1 & 1 \\
\hline colectomy & 26 & 3 & 5 & 10 & 4 & & 10 & 1 & \\
\hline Ileostomy & 7 & 6 & & & 2 & & 3 & 1 & 2 \\
\hline $\begin{array}{l}\text { colectomy } \\
\text { Ileostomy, total }\end{array}$ & 14 & & & & 1 & & 10 & & 2 \\
\hline proctocolectomy & 1 & & & & & 1 & & & \\
\hline & & & & & & & & & \\
\hline Total & 68 & 21 & 10 & 22 & 9 & 3 & 29 & 3 & 5 \\
\hline
\end{tabular}

${ }^{1}$ Anastomosis to sigmoid in 14 (with exclusion in 7), to descending in 1 , to transverse in 3.

${ }^{2}$ Anastomosis to sigmoid in 17 , to descending in 1 , to transverse in 6 , to ascending in 1 , to rectum in 1 . 
43 cases the operation was done between 1952 and 1963 after a mean of five years of disease.

SURGICAL THERAPY The nature of the primary procedures in 68 cases is noted in Table VI. In only 21 patients was one major operation performed; 47 patients required a total of 144 additional major procedures. The nature of the later operations following each type of initial procedure is also noted in Table VI, and the total number of major operations per patient and per initial procedure is described in Table VII.

The total number of all operations and the number per patient are shown in Table VIII. These include the drainage of abscesses, excision of sinus tracts, supplementary bowel resections, and ileostomy revisions.

EXTENSION OF INFLAMMATORY DISEASE IN SURGICAL CASES In 42 of the 68 surgically treated cases $(62 \%)$ there was extension of inflammatory disease distally to the rectum with ultimate resection of the rectal segment in 33. Table IX describes these cases and correlates the extension with the nature of the primary surgical procedure. In four cases the rectum became involved before definitive surgery. Similarly, in 30 surgically treated cases there was extension of inflammatory disease proximally $(44 \%)$ to the new

\section{TABLE VII}

NO. OF MAJOR OPERATIONS PER PATIENT ACCORDING TO PRIMARY PROCEDURE IN 68 CASES OF INFLAMMATORY DISEASE OF THE COLON INITIALLY SPARING THE RECTUM

\begin{tabular}{|c|c|c|c|c|}
\hline \multirow[t]{2}{*}{$\begin{array}{l}\text { Primary Definitive } \\
\text { Operation }\end{array}$} & \multirow{2}{*}{$\begin{array}{l}\text { No. of Cases } \\
\text { with } \\
\text { Primary } \\
\text { Operation } \\
\text { Only }\end{array}$} & \multicolumn{2}{|c|}{$\begin{array}{l}\text { Later } \\
\text { Operations }\end{array}$} & \multirow{2}{*}{$\begin{array}{l}\text { Total No. } \\
\text { of Major } \\
\text { Operation. }\end{array}$} \\
\hline & & $\begin{array}{l}\text { No. of } \\
\text { Cases }\end{array}$ & Total & \\
\hline $\begin{array}{l}\text { Ileocolostomy } \\
\text { Ileocolostomy, }\end{array}$ & 5 & 13 & 54 & 59 \\
\hline $\begin{array}{l}\text { subtotal colectomy } \\
\text { Ileostomy }\end{array}$ & $\begin{array}{r}13 \\
0\end{array}$ & $\begin{array}{r}13 \\
7\end{array}$ & $\begin{array}{l}42 \\
20\end{array}$ & $\begin{array}{l}55 \\
20\end{array}$ \\
\hline $\begin{array}{l}\text { Ileostomy, } \\
\text { subtotal colectomy } \\
\text { Ileostomy, total }\end{array}$ & 2 & 12 & 24 & 26 \\
\hline $\begin{array}{l}\text { proctocolectomy } \\
\text { Ileal resection }\end{array}$ & $\begin{array}{l}0 \\
1\end{array}$ & $\begin{array}{l}1 \\
1\end{array}$ & $\begin{array}{l}2 \\
2\end{array}$ & $\begin{array}{l}2 \\
3\end{array}$ \\
\hline Totals & 21 & 47 & 144 & 165 \\
\hline
\end{tabular}

TABLE VIII

TOTAL NO. OF MAJOR AND MINOR OPERATIONS IN 72 PATIENTS WITH INFLAMMATORY DISEASE OF THE COLON INITIALLY SPARING THE RECTUM

Total

\begin{tabular}{lrrrrrrrrrrr}
\hline No. of operations & 1 & 2 & 3 & 4 & 5 & 6 & 7 & 8 & 11 & 12 & 266 \\
No. of patients & 17 & 16 & 8 & 7 & 8 & 6 & 5 & 1 & 2 & 2 & 72
\end{tabular}

${ }^{1}$ Includes four patients with exploration or minor procedures only. Average 3.8 operations per patient.

TABLE IX

DISTAL EXTENSION OF INFLAMMATORY DISEASE OF THE COLON INITIALLY SPARING THE RECTUM IN 68 SURGICALLY TREATED CASES CORRELATED WITH PRIMARY OPERATIONS

\begin{tabular}{|c|c|c|c|c|c|c|c|}
\hline \multirow[t]{2}{*}{ Initial Definitive Operation } & \multirow{2}{*}{$\begin{array}{l}\text { Total No. } \\
\text { of Cases }\end{array}$} & \multirow{2}{*}{$\begin{array}{l}\text { No. of Cases } \\
\text { with Rectum } \\
\text { Free of } \\
\text { Disease }\end{array}$} & \multicolumn{4}{|c|}{ No. of Cases with Extension of Disease to Rectum } & \multirow{2}{*}{$\begin{array}{l}\text { No. of Cases } \\
\text {-with Rectum } \\
\text { Resected }\end{array}$} \\
\hline & & & Total & $\begin{array}{l}\text { Without } \\
\text { Further } \\
\text { Surgery }\end{array}$ & $\begin{array}{l}\text { After } \\
\text { Further } \\
\text { Surgery }\end{array}$ & $\begin{array}{l}\text { Before } \\
\text { Primary } \\
\text { Surgery }\end{array}$ & \\
\hline $\begin{array}{l}\text { Ileocolostomy } \\
\text { Ileocolostomy, subtotal colectomy } \\
\text { Ileostomy, subtotal colectomy } \\
\text { Ileostomy, total proctocolectomy } \\
\text { Ileal resection }\end{array}$ & $\begin{array}{r}18 \\
26 \\
20 \\
2 \\
2\end{array}$ & $\begin{array}{r}5 \\
13 \\
6 \\
0 \\
2\end{array}$ & $\begin{array}{r}13 \\
13 \\
14 \\
2 \\
-\end{array}$ & $\begin{array}{r}3 \\
11 \\
10 \\
1 \\
-\end{array}$ & $\begin{array}{r}10 \\
2 \\
1 \\
-\end{array}$ & $\begin{array}{l}\overline{-} \\
1 \\
-\end{array}$ & $\begin{array}{r}7 \\
11 \\
13 \\
2 \\
0\end{array}$ \\
\hline Total & 68 & 26 & 42 & 25 & 13 & 4 & 33 \\
\hline
\end{tabular}

TABLE X

PROXIMAL EXTENSION OF INFLAMMATORY DISEASE OF THE COLON INITIALLY SPARING THE RECTUM IN 68 SURGICALLY TREATED CASES CORRELATED WITH PRIMARY OPERATIONS

\begin{tabular}{|c|c|c|c|c|c|c|c|}
\hline \multirow[t]{2}{*}{ Initial Definitive Operation } & \multirow[t]{2}{*}{$\begin{array}{l}\text { Total No. } \\
\text { of Cases }\end{array}$} & \multirow{2}{*}{$\begin{array}{l}\text { No. of Cases } \\
\text { with Ileum } \\
\text { Free of } \\
\text { Disease }\end{array}$} & \multicolumn{3}{|c|}{$\begin{array}{l}\text { No. of Cases with Extension of Disease to } \\
\text { Ileum }\end{array}$} & \multicolumn{2}{|c|}{$\begin{array}{l}\text { No. of Cases with Further } \\
\text { Small Bowel Surgery }\end{array}$} \\
\hline & & & Total & $\begin{array}{l}\text { Without } \\
\text { Further } \\
\text { Surgery }\end{array}$ & $\begin{array}{l}\text { After } \\
\text { Further } \\
\text { Surgery }\end{array}$ & Ileostomy & $\begin{array}{l}\text { Ileal } \\
\text { Resection }\end{array}$ \\
\hline $\begin{array}{l}\text { Ileocolostomy } \\
\text { Ileocolostomy, subtotal colectomy } \\
\text { Ileostomy, subtotal colectomy } \\
\text { Ileostomy, total proctocolectomy } \\
\text { Ileal resection }\end{array}$ & $\begin{array}{r}18 \\
26 \\
20 \\
2 \\
2\end{array}$ & $\begin{array}{r}6 \\
13 \\
16 \\
0 \\
1\end{array}$ & $\begin{array}{r}12 \\
11 \\
4 \\
2 \\
1\end{array}$ & $\begin{array}{l}4 \\
9 \\
3 \\
1 \\
1\end{array}$ & $\begin{array}{l}8 \\
2 \\
1 \\
1 \\
-\end{array}$ & $\begin{array}{r}10 \\
7 \\
- \\
-\end{array}$ & $\begin{array}{l}3 \\
2 \\
1 \\
1\end{array}$ \\
\hline Total & 68 & 36 & 30 & 18 & 12 & 17 & 7 \\
\hline
\end{tabular}

${ }^{1}$ Ileal resection at time of ileostomy in five. 
terminal ileum as shown in Table $\mathrm{X}$, with later ileal resections in 12 .

The extension of inflammatory disease both distally and proximally is correlated with most of the major definitive surgical procedures in Table XI. In only $16 \%$ was there neither proximal nor distal spread of disease after colonic resection. Table XII describes the time interval until evidence of spread of inflammatory disease following the surgical procedure. These figures are likely to be longer than the true times in that often the extension was not identified until the patient was again admitted to the hospital for additional surgery. Any discrepancy in figures between these two tables and other data can be accounted for by deaths following previous surgery or by insufficient time to evaluate extension following the last surgical procedure.

The influence of the original extent of inflam- matory disease on the future clinical course and proximal spread is summarized in Table XIII.

LATE RESUlTS AND PRESENT STATUS A summary of the course of the disease is outlined in Table XIV, indicating the final surgical status of 68 patients, the final incidence of extension of disease to the rectum in all cases, the end result of the rectal segment, the final state of health, and the mortality. Extension of inflammatory disease proximally since the last surgical procedure is noted. At the time of follow-up only seven patients had the original ileocolostomies, all except one with subtotal colectomy, without extension of disease to either the rectum or ileum after five to 12 years.

Eleven patients died as a result of the inflammatory disease. Six deaths were related to operative procedures, three were caused by ileostomy com-

TABLE XI

EXTENSION OF DISEASE FOLLOWING 110 DEFINITIVE SURGICAL PROCEDURES IN 68 CASES OF INFLAMMATORY DISEASE OF THE COLON INITIALLY SPARING THE RECTUM

Surgical Procedures

\begin{tabular}{|c|c|c|c|c|}
\hline No. of & Extension & & & \\
\hline & $\begin{array}{l}\text { No. of Cases } \\
\text { Distally }\end{array}$ & $\begin{array}{l}\text { No. of Cases } \\
\text { Proximally }\end{array}$ & $\begin{array}{l}\text { No. of Cases } \\
\text { to Both }\end{array}$ & $\begin{array}{l}\text { No. of Cases } \\
\text { to Neither }\end{array}$ \\
\hline $\begin{array}{l}18 \\
61\end{array}$ & $\begin{array}{r}3 \\
33\end{array}$ & $\begin{array}{r}4 \\
24\end{array}$ & $\begin{array}{r}1 \\
11\end{array}$ & $\begin{array}{r}0 \\
10\end{array}$ \\
\hline $\begin{array}{r}13 \\
26 \\
7 \\
15\end{array}$ & $\begin{array}{r}7 \\
11 \\
5 \\
10\end{array}$ & $\begin{array}{r}6 \\
10 \\
4 \\
4\end{array}$ & $\begin{array}{l}3 \\
6 \\
1 \\
1\end{array}$ & $\begin{array}{l}0 \\
6 \\
1 \\
3\end{array}$ \\
\hline 9 & 3 & 5 & 2 & 2 \\
\hline 2 & 1 & 1 & 1 & 1 \\
\hline 1 & 0 & 0 & 0 & 1 \\
\hline 5 & 3 & 1 & 1 & 2 \\
\hline 15 & 0 & 4 & 0 & 0 \\
\hline 111 & $\begin{array}{l}43 \\
(38.7 \%)\end{array}$ & $\begin{array}{l}39 \\
(35.1 \%)\end{array}$ & $\begin{array}{l}16 \\
(14.4 \%)\end{array}$ & $\begin{array}{l}16 \\
(14.4 \%)\end{array}$ \\
\hline
\end{tabular}

TABLE XII

Ileocolostomy

Colonic resection

Following previous ileocolostomy

With ileocolostomy

Following previous ileostomy

With ileostomy

Resection of internal anastomosis with new anastomosis

Resection of internal anastomosis with new anastomosis (2nd)

Resection of internal anastomosis with new anastomosis (3rd)

Re-anastomosis

Ileal resection

$(38.7 \%)$

$(35.1 \%)$

$(14.4 \%)$

APPROXIMATE TIME UNTIL EXTENSION DISTALLY AND PROXIMALLY FOLLOWING 42 DEFINITIVE SURGICAL PROCEDURES FOR INFLAMMATORY DISEASE OF THE COLON INITIALLY SPARING THE RECTUM

\begin{tabular}{|c|c|c|c|c|}
\hline \multirow[t]{2}{*}{ Surgical Procedure } & \multicolumn{2}{|c|}{ Distal Extension } & \multicolumn{2}{|c|}{ Proximal Extension } \\
\hline & No. of Cases & $\begin{array}{l}\text { Time since } \\
\text { Operation }(y r .)\end{array}$ & No. of Cases & $\begin{array}{l}\text { Time since } \\
\text { Operation }(y r .)\end{array}$ \\
\hline Ileocolostomy & 3 & $1,2,9$ & 4 & $2,4,9,12$ \\
\hline \multicolumn{5}{|l|}{ Colonic resection } \\
\hline Following previous ileocolostomy & 6 & $\frac{1}{2}, 1,3,4,7,10$ & 6 & $\frac{1}{2}, 1,2,4,4 \frac{1}{2}, 7$ \\
\hline With ileocolostomy & 11 & $8,1,1,1 \frac{1}{2}, 3,4,4,5,7$ & 10 & $1,1,3,4,4,4,5,5,10,11$ \\
\hline Following previous ileostomy & 5 & $1,1,1,3,5 \frac{1}{2}$ & 3 & $2,6,7$ \\
\hline With ileostomy & 10 & $\frac{1}{2}, 1,2,2,2,3 \frac{1}{2}, 4,6,9$ & 3 & $1,2,4$ \\
\hline $\begin{array}{l}\text { Ileostomy, total proctocolectomy } \\
\text { Primary ileal resection }\end{array}$ & & & $\begin{array}{l}2 \\
1\end{array}$ & 3,5 \\
\hline Re-anastomosis & 3 & $2 \frac{1}{2}, 7,11$ & 1 & 4 \\
\hline Resection of internal anastomosis with new anastomosis & 3 & $1 / 12,3,3$ & 5 & $1 / 12,1 / 12,1,6,7$ \\
\hline New anastomosis (2nd) & 1 & $2 \frac{1}{2}$ & 1 & \\
\hline Ileal resection & & & 4 & $4,5,7,10$ \\
\hline
\end{tabular}


TABLE XIII

INFLUENCE OF ORIGINAL EXTENT OF INVOLVEMENT ON LATER COURSE IN 75 CASES OF INFLAMMATORY DISEASE OF THE COLON INITIAL急Y SPARING THE RECTUM

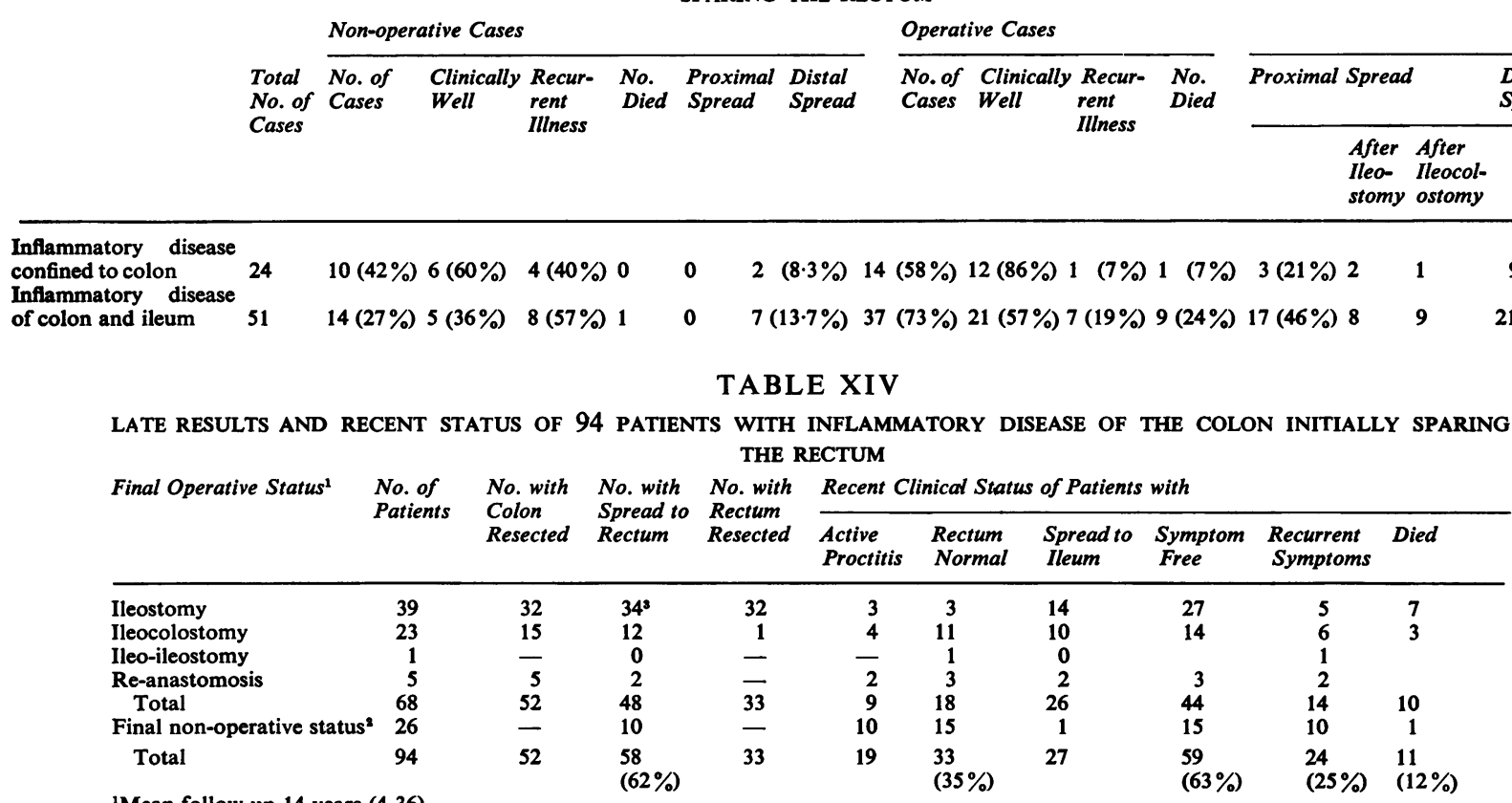

${ }^{1}$ Mean follow-up 14 years (4-36).

${ }^{2}$ Mean follow-up 11 years (4-36).

${ }^{3}$ Spread to rectum before any surgery in four.

plications, and two were related to fulminating disease. Death occurred as early as two years and as late as $\mathbf{2 8}$ years after the onset of disease.

CORRELATION OF THE CLINICAL FEATURES AND RADIOLOGICAL ASPECTS WITH THE PATHOLOGICAL MATERIAL The clinical and the radiological features were correlated with the pathological findings in the 68 surgical cases. Clinical symptoms such as bloody diarrhoea and left lower quadrant pain favoured the diagnosis of ulcerative colitis while bloodless diarrhoea and right lower quadrant pain supported the diagnosis of granulomatous colitis. $X$-ray findings of symmetrical involvement, pseudopolyposis, and serrations favoured the diagnosis of ulcerative colitis, while asymmetrical involvement, skip areas, internal fistulae and some strictures supported the diagnosis of granulomatous disease. Involvement of the ileum was not used to support the granulomatous nature of the disease unless it was strictured as in ileitis or there was more than a foot of involvement. The sparing of the rectum was, of course, initially common to all cases, though if the disease extended to the rectum before any surgery, and sigmoidoscopy then resulted in the typical appearance of ulcerative colitis, it influenced the classification of the case.
The pathological reports of specimens as originally reported by the surgical pathologists of the hospital were reviewed. The disease was considered granulomatous when the colon was grossly thickened or when histologically granulomata, giant cells, or epithelioid cells were found in the colon, rectum, ileum, or lymph nodes.

Linear or longitudinal ulcerations or scars, considered a diagnostic radiological feature of granulomatous colitis, were found in 14 cases. In seven the granulomatous nature was confirmed histologically and in the other seven the surgical specimens were grossly thickened and probably also granulomatous.

Of 65 patients with adequate pathological descriptions of surgical specimens, $47(72 \%)$ had evidence of granulomatous disease. In 12 of these the surgical specimen was thickened and grossly granulomatous but without histological confirmation.

Of the 35 cases pathologically granulomatous, the diagnosis was made on histological examination of the colon itself in at least 31 and of the ileum in two. The granulomatous nature was determined by examination of one surgical specimen in 18 and two specimens in seven; in the other 10 there was a second surgical specimen more consistent with ulcerative than granulomatous colitis. In 13 the 
rectum was later resected and revealed evidence of granulomatous disease in six and ulcerative colitis in seven. Of the 12 cases with gross evidence of granulomatous disease without histological confirmation, the rectum was later resected in six and histologically revealed ulcerative colitis in all. There was evidence of granulomatous disease in the lymph nodes in five cases.

The other 18 cases were reported as of ulcerative colitis on the basis of examination of one surgical specimen in five, two specimens in 11, and three specimens in two.

In 56 patients adequate descriptions of the clinical and radiological features were available to correlate with the pathological findings (Table XV). Accord-

\section{TABLE XV}

CORRELATION OF CLINICAL AND RADIOLOGICAL WITH PATHOLOGICAL CLASSIFICATIONS IN 56 CASES OF INFLAMMATORY DISEASE OF THE COLON INITIALLY SPARING THE RECTUM

\begin{tabular}{llllll} 
& & & \multicolumn{2}{c}{ Pathological } \\
\cline { 4 - 5 } & & & \multicolumn{2}{c}{ Ulcerative $\begin{array}{l}\text { Granulo- } \\
\text { matous }\end{array}$} \\
\cline { 4 - 5 } Clinical & Radiological & Total No. & No. & No. \\
\hline Ulcerative & Ulcerative & $23(41 \%)$ & $8(35 \%)$ & $15(65 \%)$ \\
Granulomatous & Granulomatous & $16(28 \%)$ & $2(12 \%)$ & $14(88 \%)$ \\
Ulcerative & Granulomatous & $2(4 \%)$ & 1 & 1 \\
Granulomatous & Ulcerative & $15(27 \%)$ & $5(33 \%)$ & $10(67 \%)$ \\
Total & & $56(100 \%)$ & $16(29 \%)$ & $40(71 \%)$
\end{tabular}

ingly, the diagnostic value of clinical and radiological features in determining the granulomatous nature of the colitis in 65 patients with inflammatory disease of the colon initially sparing the rectum is as follows:

Clinically ulcerative. . . $67 \%$ granulomatous Clinically granulomatous $\quad . . \quad 77 \%$ granulomatous Radiologically ulcerative .. $69 \%$ granulomatous Radiologically granulomatous .. $\quad . \quad 84 \%$ granulomatous Clinically and radiologically

granulomatous .. $\quad \ldots \quad 88 \%$ granulomatous

\section{DISCUSSION}

Sparing of the rectum has had little or no influence on specific medical management but with indication for surgical intervention has encouraged internal anastomoses, successful in some but with disastrous results in others (Garlock and Lyons, 1954; Manning, Warren, and Adi, 1955). The reasons for this are probably related to the nature of the inflammatory process. If the terminal ileum involved even minimally with regional ileitis should be transected, extension of the disease proximally would be anticipated, whereas the terminal ileum minimally involved with the ileitis associated with ulcerative colitis ('backwash') can be transected without concern (Counsell, 1956). While the same terminal ileum involved with regional ileitis can be by-passed (ileocolostomy) with reasonable hope of long-term remission and no extension of disease, a by-pass of a segment of colon involved with ulcerative colitis is less likely to fare so well. Theoretically colonic disease should be histologically more related to ileitis than to ulcerative colitis for a by-pass operation to be performed without resulting spread of the disease toward the rectum, though with an increased risk of spread proximally into the new terminal ileum.

Since the pathological concept of Crohn's disease of the colon has been popularized (Lockhart-Mummery and Morson, 1960, 1964), greater efforts have been made by surgical pathologists to distinguish this disease from ulcerative colitis in surgical specimens. The differential diagnosis if made pre-operatively in patients with sparing of the rectum might lead to an ileocolostomy if the disease were granulomatous as opposed to an ileostomy for ulcerative colitis. Such a differential diagnosis without the examination of tissue has been markedly enhanced by the classification of distinguishing radiological features (Wolf and Marshak, 1962; Lindner, Marshak, Wolf, and Janowitz, 1963).

In this study the preponderance of females over males (54 to 50$)$ is similar to ulcerative colitis ( 54 to 46) but the mean age at time of onset (21) is considerably younger (29) (Korelitz and Janowitz, 1959). The complications are those expected in the course of inflammatory colonic disease which

\section{TABLE XVI}

INCIDENCE OF COMPLICATIONS OF INFLAMMATORY DISEASE OF THE COLON INITIALLY SPARING THE RECTUM COMPARED WITH ULCERATIVE COLITIS

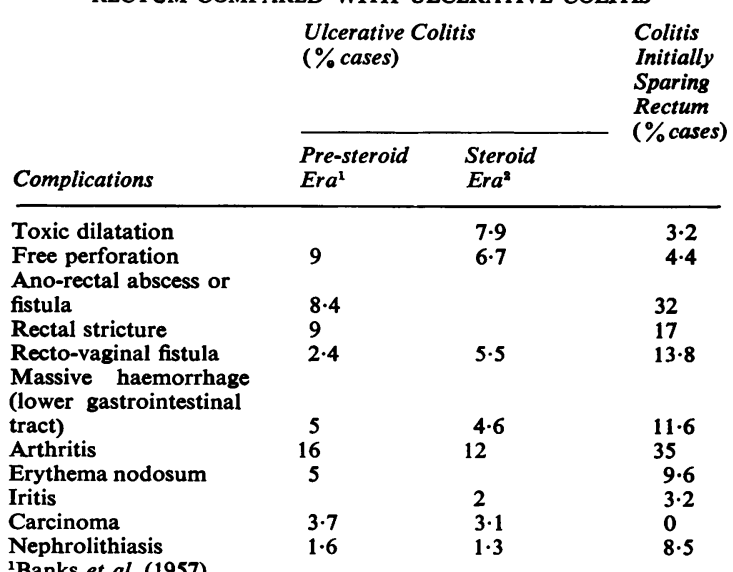

${ }^{2}$ Korelitz and Lindner (1964). 
includes the rectum, though there are notable differences in frequency in some instances (Table XVI) (Banks, Korelitz, and Zetzel, 1957; Korelitz and Lindner, 1964). Dilatation of the colon (toxic megacolon) occurred infrequently as compared with ulcerative colitis (Korelitz and Lindner, 1964); of the three cases the granulomatous nature of the primary colonic disease was confirmed in two. Though perforation of the colon was similar in incidence in both groups, in most cases there was local abscess formation rather than a free perforation as in ulcerative colitis. Massive lower gastrointestinal haemorrhage was surprisingly more common than in ulcerative colitis despite the much lower overall incidence of bleeding per rectum. Carcinoma of the rectum or colon, the dread late complication of ulcerative colitis, was not found in any of these cases. The high incidence of nephrolithiasis was notable.

There are no clear distinctions in the immediate response to a programme of medical management in these cases as opposed to ulcerative colitis. The fact that $54 \%$ of the patients with disease sparing the rectum were treated with A.C.T.H. or adrenal steroids and yet the surgical incidence was twice as high in these 94 cases as in a study of ulcerative colitis in the pre-steroid era (Banks et. al., 1957) shows that hormonal therapy is ultimately of less value. The medical success for $16 \%$ in this study is no different from that reported for right-sided colitis by Crohn, Garlock, and Yarnis 20 years ago (1947). The later operative intervention in the steroid era as opposed to the pre-steroid era can no doubt be attributed to the temporary favourable action of the hormonal agents.

The course of inflammatory disease of the colon initially sparing the rectum has led to major surgical intervention in $72 \%$. Because of the normal appearing rectal segment, an ileostomy was avoided in twothirds, an ileocolostomy with or without resection being considered the procedure of choice. With subsequent extension of the disease distally or proximally, fistula or abscess formation, obstruction, haemorrhage, perforation, or overall degeneration of health, only one-third of these required no further surgery, though an additional $11 \%$ were successful with secondary ileocolostomies; three $(7 \%)$ died of complications, and $48 \%$ needed ileostomies, often after many years of illness with or without interim surgical procedures resulting in temporary success. In one-third an ileostomy is favoured as a primary surgical procedure, usually influenced by rectal complications, perforation of the colon or ileum, or spread of disease to the rectum pre-operatively. Ultimately two-thirds of the surgical cases required ileostomy.
Confinement of the inflammatory disease to the colon itself, being more prone to cure by resection than when the ileum is also diseased was suggested in an earlier report from this institution (Janowitz, Lindner, and Marshak, 1965). When the cases of colonic disease sparing the rectum are compared with those in which the ileum also is involved from the time of diagnosis, it is clear that the former fare better in all aspects.

The nature of the primary colonic surgery as a factor in the extension of disease to the rectum seems immaterial. Though the incidence of distal involvement was considerably less following an ileocolostomy than after a colonic resection (with ileocolostomy, with ileostomy, or performed secondarily), an indication for the colonic resection usually existed without concern for its possible influence on extension.

With reference to extension of disease to the new terminal ileum, there was little difference between those treated by ileocolostomy with and those without resection. When ileostomy and subtotal colectomy were performed as a primary procedure the incidence of proximal spread was significantly less than following the internal anastomoses.

Because of extension of disease to the rectum and chronic activity in this segment, it was ultimately resected in $48.5 \%$. Because of extension of disease to the ileum, usually with complications, one or more secondary ileal resections were performed in $17 \cdot 6 \%$. These were usually in conjunction with a new anastomosis or establishment of an ileostomy. A previously constructed ileostomy was not an absolute protection against proximal spread. Recurrent ileitis occurred in five cases with ileostomy leading to resection and revision; in three the ileitis was recognized pre-operatively and in two it was discovered at exploration. The incidence of ileostomy revision in general was $32 \%$, slightly higher than in studies of ulcerative colitis $(25 \%)$.

In considering primary surgical intervention for inflammatory colonic disease sparing the rectum, the risk of provoking spread of the process either proximally or distally must be weighed against the clinical condition at the time. Acute and subacute complications such as obstruction, perforation, and abscess with fistulae require surgery. Chronic disease without complication merits careful consideration of the statistics before surgery is undertaken. The patient treated by ileocolectomy has only a $16 \%$ chance of no subsequent spread either proximally or distally, and a $54 \%$ chance of no subsequent extension proximally even if there should be spread distally requiring rectal surgery. Despite this, the decision should be influenced in some cases by the knowledge that extension of disease, if it occurs at 
all, might not do so for many years, and even then might not be of importance clinically. These factors should be considered in anticipation of secondary surgical procedures as well, though in these circumstances the possibility of a malabsorption syndrome or recurrent electrolyte imbalance associated with loss of further small bowel must also be weighed.

The behaviour of colitis and ileocolitis sparing the rectum in regard to extension of disease following surgery and lack of extension of disease without surgery is more allied to regional ileitis than ulcerative colitis and suggests that the inflammatory tissue is of a granulomatous rather than ulcerative exudative nature. It would be tempting to speculate that the $15 \%$ (14 cases) with extension of disease to the rectal segment unprovoked by surgery must be pathologically ulcerative colitis. In fact, however, there was histological evidence of granulomatous disease in all four patients on whom colectomy was later performed. In two of these there was granulomatous involvement of the rectum itself in addition to the more proximal colon. Of the 10 non-operative patients with extension of disease to the rectum, in only two did the typical sigmoidoscopic features of ulcerative colitis appear. The other eight presented a less severe picture characterized by mild or moderate friability. Two developed rectal strictures, both in association with other strictures more proximal in the colon. In at least half, the colonic involvement was still predominantly right-sided. Nevertheless, biopsies of the rectal mucosa, which were performed in most, revealed no evidence of granulomata. These observations suggest that the probably granulomatous nature of the inflammatory colonic disease cannot be negated by the late and unprovoked extension to the rectal segment.

Utilizing the radiological criteria introduced by Wolf and Marshak (1962) for distinction of granulomatous colitis from ulcerative colitis, $32 \%$ of these cases initially sparing the rectum had diagnostic radiological features of granulomatous disease. This is a very conservative appraisal in that the sparing of the rectum itself was excluded from the differential criteria. Influenced by both clinical and radiological features, a diagnosis of granulomatous disease can be made in $59 \%$ uninfluenced by the fact that the rectum is free of involvement.

Pathologically the yield of granulomatous disease was considerably higher, $72 \%$ of surgical cases. Even this figure is conservative in that this study includes many years when the concept of granulomatous disease was not yet popularized and a questionable number of these cases were reported by the pathologist as ulcerative colitis. Despite this, there was pathological evidence of granulomatous colitis in as many as $65 \%$ of these cases sparing the rectal segment even when other clinical and radiological features favoured ulcerative colitis.

Whether all of the $72 \%$ of surgical cases with Crohn's disease of the colon represent a single entity will require further consideration. Perhaps there are prognostic distinctions between the $75 \%$ with histological confirmation of granulomatous disease and the $25 \%$ with gross appearance only. It is interesting that as many as half of those which were grossly but not histologically granulomatous had radiological evidence of longitudinal ulcerations. Clinically, however, there seems to be little difference between the two types.

\section{CONCLUSION}

Inflammatory disease of the colon sparing the rectum should be considered granulomatous unless there is significant clinical or radiological evidence to the contrary. The long-term course of the disease is favourable with medical management alone in at least $16 \%$ and probably more with optimum use of the currently available therapeutic agents. If definitive surgery is performed for an absolute indication such as abscess formation, fistula, or chronic debility, an ileocolostomy should be favourably considered if the rectum remains free of disease, even allowing for the high incidence of distal extension and probably need for later surgery. If there is distal extension of disease pre-operatively or there is a perirectal complication, an ileostomy with subtotal colectomy should be favoured. An ileostomy, however, is no insurance against proximal spread. If the normal appearing rectum is retained, a re-anastomosis might be reasonably attempted at a later date should there be no proximal extension following ileostomy.

If the indications for surgery are questionable, the high incidence of extension of the disease both proximally and distally should encourage persistence in a medical programme. The less favourable surgical result if the disease extends proximal to the ileocecal valve should also encourage continued medical therapy.

\section{SUMMARY}

The course of 94 patients with inflammatory disease of the colon sparing the rectum was analyzed after a mean follow-up of 14 years. The mean age at onset was younger than in a comparable series of cases of ulcerative colitis involving the rectum. The high incidence of internal fistula formation, skip areas, perirectal suppuration and ulceration, and both rectal and colonic strictures supported a closer relationship to regional ileitis than to ulcerative 
colitis. The presence of blood in the stool was less common but massive haemorrhage was more common. Complicating arthritis, erythema nodosum, uveitis, and nephrolithiasis had a higher incidence than in ulcerative colitis while free perforation occurred less often, toxic dilatation occurred but infrequently and there were no cases of colonic carcinoma. Twenty-eight per cent were treated without operative intervention. Most received adrenal steroids. Medical therapy was successful in only $16 \%$ though surgical intervention was postponed for a mean of three years in the others. Major surgery was performed in $72 \%$; the most common indications were abdominal mass or abscess, internal fistulae and colonic obstruction. These patients required a total of 266 operations, including 165 major procedures, an average of 3.8 operations per patient. The mortality rate of surgical cases was $14.2 \%$. An ileocolostomy with or without resection was performed in two-thirds. Almost half of these later required ileostomies, while the remaining third had ileostomies from the onset.

There was extension of disease to the rectal segment in $15 \%$ unprovoked by surgical intervention and in $54 \%$ following colonic resection. There was proximal extension of disease to the new terminal ileum in $40 \%$ following colonic resection. The time until distal extension varied from months to 14 years (mean three years) and with proximal extension from months to 11 years (mean four years). At the time of follow-up, $63 \%$ were well, $25 \%$ had recurrent symptoms or complications, and $12 \%$ had died. Of the 68 surgical cases, $47 \%$ had ileostomies and $37 \%$ had internal anastomoses, including five patients with re-anastomoses.

Involvement of the terminal ileum in inflammatory disease of the colon initially sparing the rectum clearly carried a worse prognosis than when the disease was limited to the colon.

The diagnosis of granulomatous disease was made by pathological examination in $72 \%$ of surgical cases; the remainder were considered to be ulcerative colitis. The diagnostic value of clinical and radiological features in determining the pathological nature of the disease was evaluated. If the disease was both clinically and radiologically ulcerative colitis, it proved to be pathologically granulomatous in $65 \%$, while if clinically and radiologically granulomatous, it proved to be granulomatous in $88 \%$.

\section{REFERENCES}

Banks, B. M., Korelitz, B. I., and Zetzel, L. (1957). The course of non-specific ulcerative colitis: review of twenty years' experience and late results. Gastroenterology, 32, 983-1012.

Counsell, B. (1956). Lesions of the ileum associated with ulcerative colitis. Brit. J. Surg., 44, 276-290.

Crohn, B. B., Garlock, J. H., and Yarnis, H. (1947). Right-sided (regional) colitis. J. Amer. med. Ass., 134, 334-338.

Garlock, J. H., and Lyons, A. S. (1954). The role of surgery in the therapy of ulcerative colitis. Gastroenterology, 26, 709-722.

Janowitz, H. D., Lindner, A. E., and Marshak, R. H. (1965). Granulomatous colitis: Crohn's disease of the colon. J. Amer. med. Ass., 191, 825-828.

Korelitz, B. I., and Janowitz, H. D. (1959). Ulcerative colitis-general considerations. In Diseases of the Colon and Anorectum, edited by R. Turrell, vol. 2, pp. 658-701. Saunders, Philadelphia.

- , and Lindner, A. E. (1964). The influence of corticotrophin and adrenal steroids in the course of ulcerative colitis: a comparison with the presteroid era. Gastroenterology, 46, 671-679.

Lindner, A. E., Marshak, R. H., Wolf, B. S., and Janowitz, H. D. (1963). Granulomatous colitis. New Engl. J. Med., 269, 379-385.

Lockhart-Mummery, H. E., and Morson, B. C. (1960). Crohn's disease (regional enteritis) of the large intestine and its distinction from ulcerative colitis. Gut, 1, 87-105.

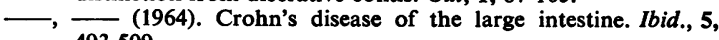
493-509.

Manning, J. H., Warren, R., and Adi, A. S. (1955). Segmental colitis: results of surgery. New Engl. J. Med., 252, 850-853.

Wolf, B. S., and Marshak, R. H. (1962). Granulomatous colitis (Crohn's disease of the colon). Roentgen features. Amer. J. Roentgenol., 88, 662-670. 